\title{
Development and Characterization of a New Cell Line from Olive Flounder Paralichthys olivaceus
}

\author{
Ju-Won Kim¹, Bang Geun Oh${ }^{1}$, Julan Kim¹, Dong-Gyun Kim¹, Bo-Hye Nam¹, Young-Ok Kim¹, \\ Jung Youn Park ${ }^{1}$, JaeHun Cheong ${ }^{2}$, and ${ }^{\dagger}$ Hee Jeong Kong ${ }^{1}$ \\ ${ }^{1}$ Biotechnology Research Division, National Institute of Fisheries Science, Busan 46083, Korea \\ ${ }^{2}$ Dept. of Integrated Biological Science, Pusan National University, Busan 43241, Korea
}

\begin{abstract}
A new embryonic cell line (OFEC-17FEN) derived from olive flounder Paralichthys olivaceus was developed. OFEC-17FEN cells were subcultured for <30 passages over $\sim 200$ days. OFEC-17FEN cells had a doubling time of $114.34 \mathrm{~h}$ and modal diploid chromosome number was 48. The pluripotency genes POU5f1 and NANOG were expressed in OFEC17FEN cells. However, the lack of several pluripotency-related genes expression indicates that OFEC-17FEN cells are not stem cells. OFEC-17FEN cells transfected with plasmid pEGFP-c1 exhibited a strong green fluorescent signal at $48 \mathrm{~h}$ after transfection. Accordingly, OFEC-17FEN cells may be useful for both basic research and biotechnological application.
\end{abstract}

Key words : Olive flounder, Embryo, Primary cell culture, Cell line

\section{INTRODUCTION}

Olive flounder (Paralichthys olivaceus), a flatfish species, is most important fish species for aquaculture in Asian countries, including Korea, Japan and China (Zheng \& Sun, 2011). Olive flounder, which has a flattened oval body, occurs mainly in benthos at depths of 10 to $200 \mathrm{~m}$ and is widely distributed in the water surrounding Korea (Park et al., 2012). Olive flounder is cultivated mainly on the southern coast of Korea and Jeju Island, and its demand is increasing gradually (Kim et al., 2014).

Fishes are ideal subjects for developing cell lines as they are of considerable interest for basic studies in molecular, cellular and developmental biology as well as for commercial purposes. Second, fishes are characterized by high fecundity, large transparent embryos and rapid development (Alvarez et al., 2007). Cell lines are important for research in virology, immunology, genetics, oncology, developmental biology, toxicology, medicine, biotechnology, epidemiology, molecular carcinogenesis and functional genomics (Gomez-Lechon et al., 2008; Wang et al., 2010). Recent studies have evaluated chilling injury, cooling rates and cryoprotectant toxicity in various fish species (Suzuki et al., 1995; Zhang et al., 1995; Robertson, 1998).

The first fish cell line established was embryonic cells from rainbow trout (Oncorhynchus mykiss) (Wolf \& Quimby, 1962), followed by Coho salmon (Oncorhynchus kisutch) (Ristow \& De Avila, 1994), white bass (Morone chrysops) (Shimizu et al., 2003), sea perch (Lateolabrax japonicus) (Chen et al., 2003a), red sea bream (Chrysophrys major)

\footnotetext{
Manuscript received July 12, 2018, Received in revised form August 7, 2018, Accepted August 31, 2018

${ }^{\dagger}$ Corresponding Author: Hee Jeong Kong, Biotechnology Research Division, National Institute of Fisheries Science, Busan 46083, Korea. Tel: +82-51720-2457, Fax: +82-51-720-2456, E-mail: heejkong@korea.kr
}

This is an Open Access article distributed under the terms of the Creative Commons Attribution Non-Commercial License (http:// creative-commons.org/licenses/by-nc/3.0) which permits unrestricted non-commercial use, distribution, and reproduction in any medium, provided the original work is properly cited. 
(Chen et al., 2003b), haddock (Melanogrammus aeglefinus) (Bryson et al., 2006), Atlantic cod (Gadus morhua) (Holen et al., 2010), marin medaka (Oryzias dancena) (Lee et al., 2013), Honmoroko (Gnathopogon caerulescens) (Higaki et al., 2015) and Nile tilapia (Oreochromis niloticus) (Fan et al., 2017). To develop embryonic stem cell lines, a gene-targeting approach has been used in, for example, zebrafish (Danio rerio) and medaka (Oryzias latipes) (Hong et al., 1996; Chen et al., 2003a). Such cell lines can be used to produce knockout fish for in vivo analysis of gene function (Hong et al., 1996).

To date, several olive flounder cell lines have been developed: FG-9307 (flounder gill 9307) cells (Tong et al., 1998), Hirame natural embryonic cells (HINAE) (Kasai \& Yoshimizu, 2001), flounder spleen and gill cells (Kang et al., 2003), flounder embryonic cells (Chen et al., 2004) and Paralichthys olivaceus brain cells (Zheng et al., 2015). It is important to establish various useful cell lines from olive flounder for basic research and biotechnological application.

Therefore, the purpose of this study is to develop new cell line that can be used for various research areas, instead of previous developed olive flounder cell lines. Here, a multipotent olive flounder cell line was developed by primary culture of embryonic cells. This cell line was characterized in terms of chromosomal abnormalities, growth, expression of pluripotency genes and transfection ability.

\section{MATERIALS AND METHODS}

\section{Primary cell culture and media supplements}

Blastula-stage flounder embryos were harvested after 8 $\mathrm{h}$ in seawater at $18^{\circ} \mathrm{C}$ post-fertilization and prepared for cell culture. For each culture, $\sim 50-70$ embryos were treated with antibiotics $(1 \times)$, washed with DPBS (Gibco) and homogenized. The chorion membranes and cell debris were removed using the $40 \mu \mathrm{m}$ cell strainer. The homogenate was centrifuged at $195 \times \mathrm{g}$ for $15 \mathrm{~min}$ at $20^{\circ} \mathrm{C}$, and single cells were harvested by gentle pipetting. After sev- eral washes with growth medium (GM), the cells were transferred to GM in a cell culture flask (surface area 25 $\mathrm{cm}^{2}$ ) (Corning).

Leibovitz's L-15 complete GM (L-15, Gibco) supplemented with antibiotic-antimycotic (Gibco), fetal bovine serum (FBS, Gibco), flounder serum (FS), flounder embryo extract (EE).

For prepare the FS and EE, blood samples were collected from olive flounder and allowed to clot at $4{ }^{\circ} \mathrm{C}$ for $4 \mathrm{~h}$. After centrifugation, the FS was collected into new flash tubes, heat-inactivated in a water bath at $56^{\circ} \mathrm{C}$ for $30 \mathrm{~min}$ and subjected to membrane filtration $(0.2 \mu \mathrm{m})$ to generate FS. Olive flounder embryos were washed with Dulbecco's phosphate-buffered saline (DPBS; Gibco) supplemented with $4 \%$ antibiotics and homogenized on ice using a glass homogenizer. The homogenate was centrifuged at $1,750 \times \mathrm{g}$ for $20 \mathrm{~min}$ at $4^{\circ} \mathrm{C}$. The supernatant (EE) was collected, filter-sterilized and stored at $-20^{\circ} \mathrm{C}$ until use. FS and EE concentrations were determined by the Warburg-Christian assay using the NanoVue spectrophotometer (GE Healthcare) (data not shown).

\section{Subculture}

Embryonic cell line which named OFEC-17FEN was cultured at $20^{\circ} \mathrm{C}$ in an incubator, and the medium was changed every 2-3 days. Upon reaching $80 \%$ confluence, the cells were subcultured at a ratio of 1:2 according to a standard trypsinization method. Briefly, cells were washed twice with GM and dissociated in trypsin-ethylenediaminetetraacetic acid (EDTA) (Gibco) solution for $4 \mathrm{~min}$ at room temperature. The trypsin-EDTA solution was removed, and GM was added. For cryopreservation, cell cultures were suspended in $1 \mathrm{~mL}$ GM with $10 \%$ dimethyl sulfoxide (Sigma-Aldrich) and 50\% FBS and then stored in isopropyl alcohol at $-80^{\circ} \mathrm{C}$.

\section{Cell proliferation assay}

Cells in GM were seeded at $3.5 \times 10^{4}$ per well into five 
wells of a 24-well plate (Corning). The cells were incubated for 8 days at $20^{\circ} \mathrm{C}$, with a medium change every 3 days. Next, cells were suspended in trypsin-EDTA for $4 \mathrm{~min}$, centrifuged for $5 \mathrm{~min}$ at $280 \times \mathrm{g}$ at $20^{\circ} \mathrm{C}$, and the trypsinEDTA was replaced with GM $(1 \mathrm{~mL})$. Cells were counted daily using a hemocytometer (Sigma, Bright-Line). Doubling time was calculated using the linear part of the growth curve as follows: Doubling time $=$ duration $\times \log (2) \div[\log ($ final conc.)-Log(initial conc.)].

\section{Chromosome analysis}

OFEC-17FEN cells (21 passages) were used for chromosome analysis according to a previously published method (Wang et al., 2010) with slight modifications. Briefly, cells were treated with $1 \mu \mathrm{g} / \mathrm{mL}$ colchicine (Sigma) for $3 \mathrm{~h}$ at $24^{\circ} \mathrm{C}$, then harvested by scraping the flask using a sterile cell scraper (SPL; $290 \mathrm{~mm}$ length, $20 \mathrm{~mm}$ blade) and suspended in $0.075 \mathrm{M} \mathrm{KCl}$, then incubated for $20 \mathrm{~min}$ at room temperature. The $\mathrm{KCl}$ was removed, and $4 \mathrm{~mL}$ methanol: acetic acid (3:1) fixative solution were added gently but rapidly using a glass Pasteur pipette (Volac; $230 \mathrm{~mm}$ ). The cells were incubated at room temperature for $30 \mathrm{~min}$, $2 \times$ fixative solution was added, and the cells were dropped onto a fixative solution-treated slide glass and stained for 8 min with $8 \%$ Giemsa (Gibco). Finally, chromosomes of over 100 metaphase cells in OFEC-17FEN cells were visualized under microscope (Leica, DE/EM6000B) using oil immersion optics (Merck KGaA) at 1,000× magnification.

\section{Pluripotency genes expression analysis}

Expression of pluripotency genes was evaluated in OFEC-17FEN cells (11 passages) and in 4-, 8-, 16-, 32and 64-cell-stage and morula-stage embryos. Total RNA was extracted from OFEC-17FEN cells using TRIzol ${ }^{\circledR}$ (Ambion) according to the manufacturer's instructions. Total RNA was treated with DNase (Promega), and $0.5 \mu \mathrm{g}$ was reverse transcribed into cDNA using the First-Strand cDNA Synthesis Kit (Roche) according to the manufactur- er's instructions.

Segments of the POU domain, class 5, transcription factor 1 (POU5f1), also known as sex determining region Y-box 2 (SOX2), NANOG, PR domain containing 14 (PRDM14), Krüppel-like factor 4 (KLF4), Sal-like protein 4 (SALL4) and $18 \mathrm{~S}$ ribosomal RNA (18S) genes were amplified by reverse transcriptase polymerase chain reaction (RT-PCR) using PCR PreMix (AccuPower PCR Primix and Master Mix, Bioneer) according to the manufacturer's instructions. Briefly, $1 \mu \mathrm{L}$ template cDNA was mixed with $1 \mu \mathrm{L}$ (10 pmol) each primer (Table 1), $7 \mu \mathrm{L}$ distilled water and $10 \mu \mathrm{L}$ PreMix. RT-PCR involved an initial denaturation step of $5 \mathrm{~min}$ at $95^{\circ} \mathrm{C}$, followed by 30 cycles of denaturation for $30 \mathrm{~s}$ at $95^{\circ} \mathrm{C}$, annealing for $30 \mathrm{~s}$ at $55^{\circ} \mathrm{C}\left(60^{\circ} \mathrm{C}\right.$ for SOX2 and KLF4) and extension for $30 \mathrm{~s}$ at $72^{\circ} \mathrm{C}$. The RTPCR products were electrophoresed on a $1.5 \%$ agarose gel.

\section{Transfection}

OFEC-17FEN cells (26 passages) were seeded at a density $5 \times 10^{4}$ per well in 24 -well plates at $20^{\circ} \mathrm{C}$. Cell monolayers $(80 \%$ confluent) were transfected with pEGFP-c1 plasmid DNA and an expression plasmid using the JetPEI kit (Polyplus) according to the manufacturer's instructions. Each well contained $1 \mu \mathrm{g} 500 \mathrm{ng}$ pEGFP-c1 plasmid DNA in $150 \mathrm{mM} \mathrm{NaCl}$ (final volume $50 \mu \mathrm{L}$ ) and $2 \mu \mathrm{L}$ jetPEI reagent in $150 \mathrm{mM} \mathrm{NaCl}$ (final volume $50 \mu \mathrm{L}$ ). Green fluorescence signals were visualized under a fluorescence microscope (Carl Zeiss, Axio Vert A1) at 48 h post-transfection.

\section{RESULTS}

\section{Primary culture}

A new olive flounder (Paralichthys olivaceus) cell line which named OFEC-17FEN was developed by primary cell culture from the blastula stage of embryos. Cell line was cultured at $20^{\circ} \mathrm{C}$ in incubator. Then first subculture was also accomplished. Morphologically, the OFEC-17FEN 
Table 1. Primers used for PCR amplification

\begin{tabular}{|c|c|c|c|c|}
\hline Primer & Length & Sequence (5'-3') & Target gene & $\begin{array}{c}\text { GeneBank } \\
\text { Accession No. }\end{array}$ \\
\hline $\begin{array}{l}\text { SOX-2 - F } \\
\text { SOX-2 - R }\end{array}$ & $503 \mathrm{bp}$ & $\begin{array}{l}\text { GCACAACTCGGAGATAAGC } \\
\text { TGGTCTGCTGGGAATAGG }\end{array}$ & $\begin{array}{l}\text { Short for sex- } \\
\text { determining } \\
\text { region } Y-\text { box } 2\end{array}$ & KF709692.1 \\
\hline $\begin{array}{l}\text { NANOG - F } \\
\text { NANOG - R }\end{array}$ & $300 \mathrm{bp}$ & $\begin{array}{l}\text { AGTCACCGACCTGAGCAACT } \\
\text { GTGGCTGACATACCTGGTGA }\end{array}$ & Nanog protein gene & KF017593 \\
\hline $\begin{array}{l}\text { PRDM14 - F } \\
\text { PRDM14 - R }\end{array}$ & $305 \mathrm{bp}$ & $\begin{array}{l}\text { AGGAGCTGCTGGTGTTGGTAT } \\
\text { GTGAGGCCTGTGTTTCTCGT }\end{array}$ & $\begin{array}{l}\text { PR domain } \\
\text { containing } 14\end{array}$ & KM624610 \\
\hline $\begin{array}{l}\text { KLF4 - F } \\
\text { KLF4 - R }\end{array}$ & $300 \mathrm{bp}$ & $\begin{array}{l}\text { GCAACTGCACCATCTCACAG } \\
\text { GGAACTGCATGGAGGATGAC }\end{array}$ & $\begin{array}{l}\text { Kruppel-like } \\
\text { factor } 4\end{array}$ & XM_020081804 \\
\hline $\begin{array}{l}\text { POU5f1 - F } \\
\text { POU5f1 - R }\end{array}$ & $315 \mathrm{bp}$ & $\begin{array}{l}\text { CAGACCCGAGCCTCCTCTAT } \\
\text { GACCCTTGATCTCCGTTGAG }\end{array}$ & $\begin{array}{l}\text { POU domain, class } 5 \text {, } \\
\text { transcription factor } 1\end{array}$ & KJ522774 \\
\hline $\begin{array}{l}\text { Sall4 - F } \\
\text { Sall4 - R }\end{array}$ & $300 \mathrm{bp}$ & $\begin{array}{l}\text { AGACCCTCACCATCAACAGG } \\
\text { GTAAGGCCTCTCTCCGGTGT }\end{array}$ & Sal-like protein 4 & XP_019960061 \\
\hline $\begin{array}{l}18 \mathrm{~s}-\mathrm{F} \\
18 \mathrm{~s}-\mathrm{R}\end{array}$ & $217 \mathrm{bp}$ & $\begin{array}{l}\text { ATGGCCGTTCTTAGTTGGTG } \\
\text { CACACGCTGATCCAGTCAGT }\end{array}$ & $\begin{array}{l}\text { 18s ribosomal } \\
\text { RNA gene }\end{array}$ & EF126037 \\
\hline
\end{tabular}

cell line was composed primarily of epithelial-like cells

(Fig. 1). To date, OFEC-17FEN cells have been subcultured for $>30$ passages over $\sim 200$ days.

\section{Cell growth curve}

OFEC-17FEN cells were evenly attached to the surface of the well within the 24 hours after seeding. Cell growth was assessed by counting cell numbers with a hemocytometer. During the growth period, the number of the cells increased, and the cells grew to confluence. Cell growth performance is shown in Fig. 2. The OFEC-17FEN cell density was $3.29 \times 10^{4} / \mathrm{mL}$ on day 1 and peaked at $9.7 \times 10^{4}$ $/ \mathrm{mL}$ on day 7 , with a doubling time of $114.34 \mathrm{~h}$ (Fig. 2). Growth curve showed a decrease in proliferation starting from day 8 . Thus, the OFEC-17FEN cell line maximum density was reached at the day 7 .

\section{Chromosome analysis}

Chromosome morphology of OFEC-17FEN is presented in Fig. 3. The chromosome numbers of the OFEC-17FEN cells were assessed at passage 21 . The result of chromosome counts of 100 metaphase revealed that the chromosome number of OFEC-17FEN cells was widely distributed between 10 and 77, with a modal peak at 48 chromosomes, and $25 \%$ of all cells contained 48 chromosomes. Chromosome numbers above and below the diploid number (Fig. 3), can be explained either by an incorrect segregation that can occur at low rate under cell culture conditions or more frequently by technical artifacts inherent to the obtention of chromosome spreads (Bejar et al., 2002). 


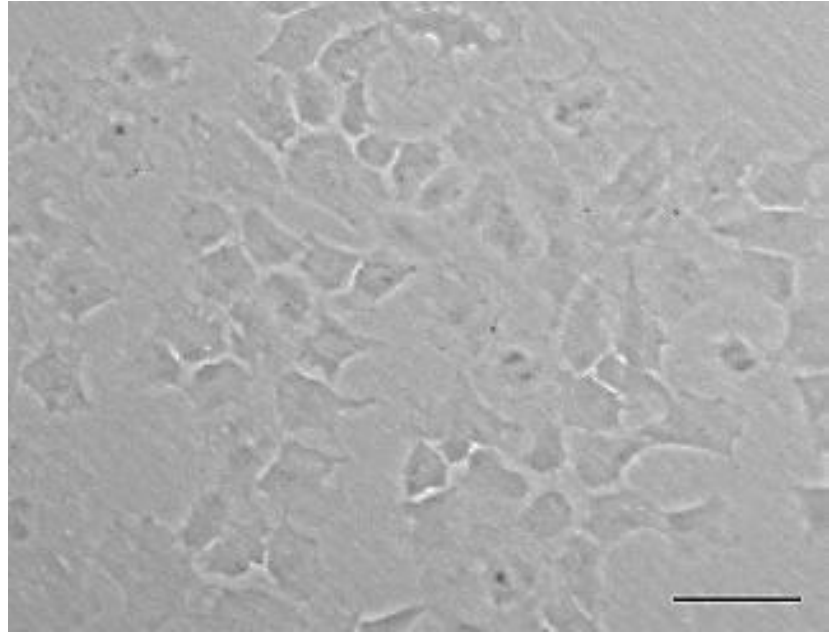

Fig. 1. The monolayers of OFEC-17FEN cells. Morphological appearance of OFEC-17FEN cells at passage 11 were analyzed by microscope (Carl Zeiss, Axio Vert, $\times 100$ ). OFEC $-17 F E N$ cells were primarily epithelial-like cell and it has been consistently subculture. Scale bar: $50 \mu \mathrm{m}$.

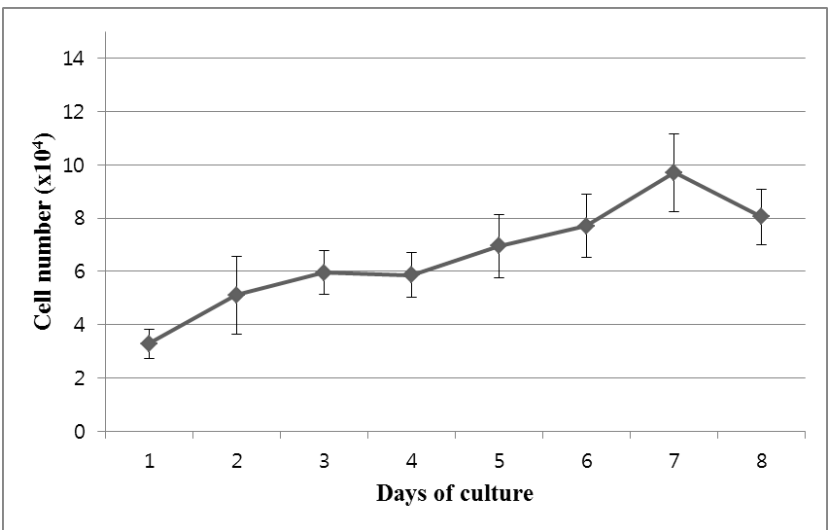

Fig. 2. Growth curve of the OFEC-17FEN cells. The cell proliferation was observed in growth curve day 1 to day 7 . The highest growth rate was showed day 7 . The population doubling time was 114.34 hours. The experiments were conducted five times in independent method. Error bar represents the standard deviation of five individual samples $(\mathrm{n}=5)$.

\section{Pluripotency genes expression}

Expression of pluripotency genes was evaluated in OFEC-17FEN cells and in 4-, 8-, 16-, 32- and 64-cellstage and morula-stage embryos. The expected $315 \mathrm{bp}$ fragment of POU5f1, $300 \mathrm{bp}$ fragment of NANOG, $503 \mathrm{bp}$

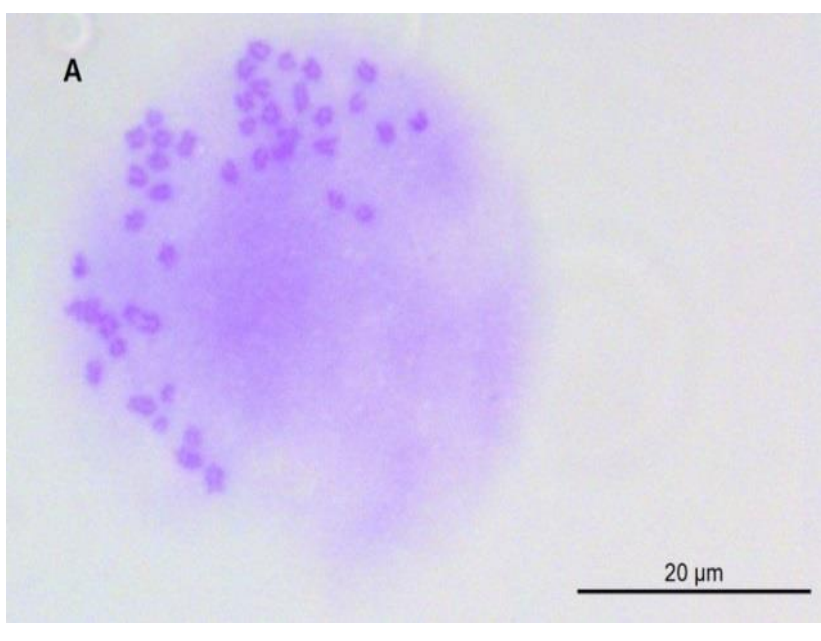

B
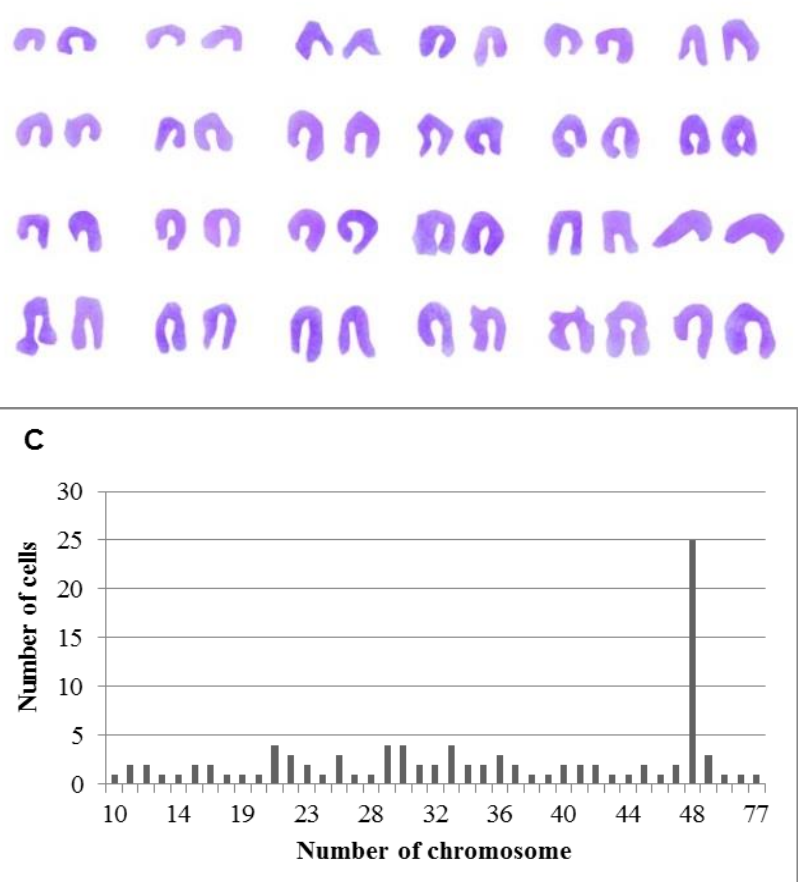

Fig. 3. Chromosome analysis of OFEC-17FEN cells at passage 21. Metaphase chromosomes of OFEC17FEN cells were prepared on slide glass. Number of chromosomes was counted after $8 \%$ Giemsa staining by microscope (Leica, DE/EM6000B). (A) Chromosomes in OFEC-17FEN cells metaphase, (B) Homologous chromosome were paired according to their size. Images of the cells containing normal chromosome number $(\mathrm{n}=48)$ from OFEC-17FEN cell line, (C) Number distribution of chromosomes in OFEC-17FEN cells. 100 metaphase cells were counted. 


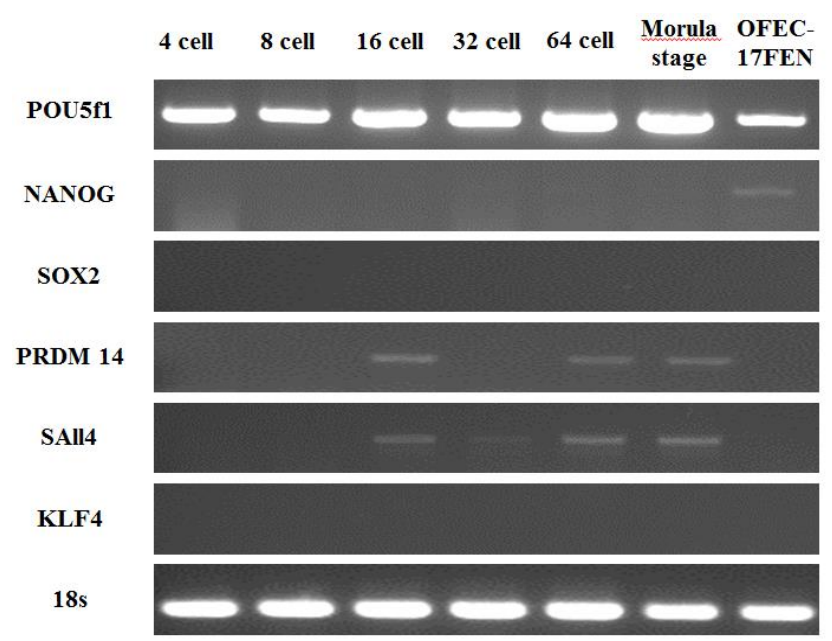

Fig. 4. Expression analysis of pluripotency related genes in OFEC-17FEN cells. The expression of pluripotency related genes including POU5f1, NANOG, SOX2, PRDM14, SAll4, and Klf4 was analyzed by RT-PCR in $1.5 \%$ agarose gel. POU5f1 and NANOG expression were observed in OFEC-17FEN cells. Expression of POU5fl gene was higher than NANOG. SOX2, PRDM14, SAll4, and Klf4 genes showed not expression in OFEC-17FEN. 18s gene was amplified as a control to show that equal amount of total RNA was used in the RT-PCR detection.

fragment of SOX2, $300 \mathrm{bp}$ fragment of SAll4, $305 \mathrm{bp}$ fragment of PRDM14 gene, $300 \mathrm{bp}$ fragment of KLF4, and 217 bp fragment of $18 \mathrm{~S}$ were analyzed by $1.5 \%$ agarose gel electrophoresis. POU5f1 expression was high in the embryos and moderate in OFEC-17FEN cells. NANOG expression was low in OFEC-17FEN cells and not detected in the embryos. SOX2 was not expressed in the embryos or OFEC17FEN cells. PRDM14 expression was low in the 16- and 64-cell-stage embryos and absent in the other stage embryos and OFEC-17FEN cells. KLF4 was not expressed in OFEC-17FEN cells or the embryos. SAll4 expression was low in the 16-, 32- and 64-cell-stage, as well as morula stage, embryos but was not detected in OFEC-17FEN cells (Fig. 4).

\section{Transfection}

To determine the transfection efficiency and gene expression of the OFEC-17FEN cells, cells were transfected
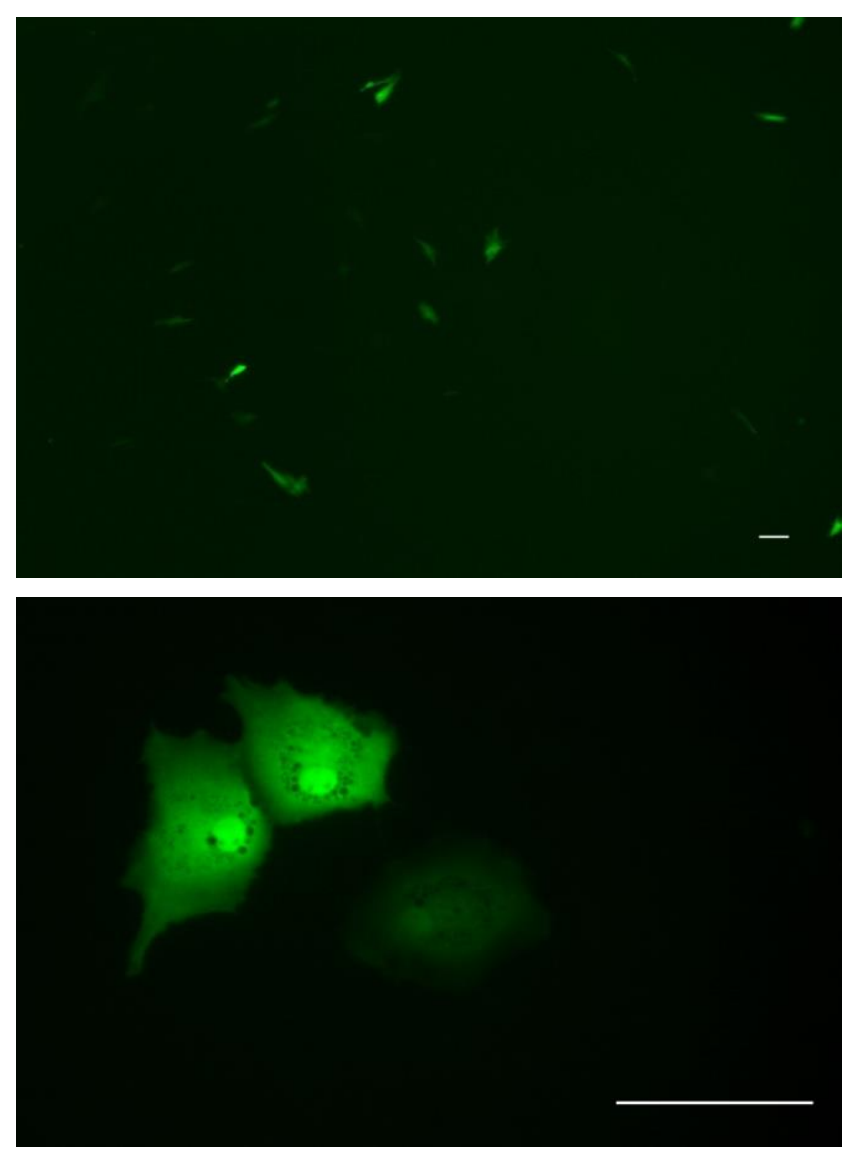

Fig. 5. Expression of GFP gene in OFEC-17FEN cells transfected with pEGFP-c1. Fluorescent micrographs of green fluorescent protein (GFP) expressed in transfected OFEC-17FEN cells using pEGFP-c1 under fluorescence microscope (Carl Zeiss, Axio Vert A1). Transfection efficiency of OFEC-17FEN cells was $10 \%-15 \%$. Scale bar: $100 \mu \mathrm{m}$.

with plasmid pEGFP-c1 by using JetPEI reagent. OFEC17FEN cells transfected with pEGFP-c1 exhibited a strong green fluorescent signal at $48 \mathrm{~h}$ after transfection. The transfection efficiency of OFEC-17FEN cells was approximately $10 \%-15 \%$ (Fig. 5). Thus, OFEC-17FEN cells are useful for exogenous gene expression which is important for both basic research and biotechnological application.

\section{DISCUSSION}

In this study, olive flounder (Paralichthys olivaceus) embryonic cell lines capable of prolonged in vitro culture 
were developed and characterized in terms of their proliferation, karyotype exogenous gene expression and transfection ability.

OFEC-17FEN cells had been continuously cultured. Morphological appearance of OFEC-17FEN cell line was primarily epithelial-like cell. In this study, Fish serum is useful for primary cell culture and promoted in vitro growth of olive flounder embryonic cells, as reported in other fish species, e.g. sea perch (Lateolabrax japonicus), red sea bream (Chrysophrys major) and turbot (Scophthalmus maximus) (Chen et al., 2003a; Chen et al., 2003b; Chen et al., 2004; Chen et al., 2005). Furthermore, there is reported that Egg Extract (EE) has mitogenic activity in fish embryos (Bejar et al., 2002) and early developmental EE reportedly promotes cell migration and growth and thus can accelerate establishment of novel cell lines (Akiduki, 2010). Thus, use FS mixed with EE in media is essential for the primary cell culture of flounder embryo. This result is interesting and meaningful finding.

Karyotype analysis of developed cell lines is important (Chen et al., 2004), particularly to assess the ability to form functional germ-line chimeras (Chen et al., 2003b). Colchicine is used in karyotype analysis because of its ability to inhibit metaphase and condense chromosomes (Foresti et al., 1993). OFEC-17FEN cells had a $2 n=48$ diploid chromosome, identical to olive flounder $(2 n=48)$ (Liu et al., 1999). Approximately $25 \%$ of OFEC-17FEN cells had 48 chromosomes, which is lower than that in other fish species (Sun et al., 1995; Hong et al., 1996; Chen et al., 2003a; Peng et al., 2016), and may be due to metamorphosis and senescence during culture, however, these phenomena were not analyzed in this study. So further investigations involving metamorphosis and senescence about OFEC-17FEN cells will be require.

The pluripotency of the cell lines was assessed by RTPCR. POU5f1, a POU domain transcription factor better known as OCT4, is critical for maintenance of the pluripotency and self-renewal of inner-cell-mass cells and for germ-line development in mice (Lachnit et al., 2008). OCT4, also known as OCT3, is involved in the selfrenewal of embryonic stem cells (Rajpert et al., 2004). SOX2 is critical for maintaining the pluripotency of embryonic and neural stem cells (Gao et al., 2014). NANOG, in conjunction with OCT4 and SOX, is involved in maintaining the pluripotency and self-renewal of embryonic stem cells (Gao et al., 2013). PRDM14 has an N-terminal PR domain and six Krüppel-type zinc finger motifs and directly regulates POU5f1 through its proximal enhancer (Fan et al., 2015). KLF4 is highly expressed in postmitotic gut and skin cells (Yu et al., 2011a). KLF4 is expressed in embryonic stem cells, and forced expression of OCT4, SOX2 and KLF4 induces reprogramming of fibroblasts into induced pluripotent stem cells (Wernig et al., 2007; Yu et al., 2011b). The SALL4 zinc finger transcription factor was first cloned based on its sequence homology to its orthologue in Drosophila spalt (Yang et al., 2007). In this study, SALL4 is expressed in two cell-stage embryos, similar to OCT4, whereas expression of SOX2 and NANOG is first shown at the blastocyst stage (Yang et al., 2010). Moreover, the expression of POU5f1 was high and that of NANOG was low, whereas SOX2, PRDM14, SALL4 and KLF4 were not expressed, in OFEC-17FEN cells. Consequently, OFEC-17FEN cells are not pluripotent. However, POU5f1 and NANOG expression suggested that OFEC-17FEN cells may have self-renewal ability. Accordingly, further investigations are needed to provide more in-depth analysis of relationship between OFEC17FEN cells function and self-renewal ability.

The OFEC-17FEN cell density was highest on day 7 and decreased thereafter, likely due to nutrient depletion (Servili et al., 2009); therefore, OFEC-17FEN cells should be subcultured after 7 days. OFEN-17FEN cells proliferated more slowly than the other cell lines but displayed a similar growth curve.

In this study, OFEC-17FEN cells exhibited a transfection rate of $10 \%-15 \%$. Primary cells are typically difficult 
to transfect, but this can generally be overcome by modifying the transfection protocol (Sassen et al., 2017). The successful transfection of pEGFP-c1 plasmid DNA suggests that OFEC-17FEN cells could facilitate exogenous gene manipulation in vitro (Huang et al., 2011).

In conclusion, the OFEC-17FEN cell line will be useful for basic research and biotechnological application.

\section{ACKNOWLEDGEMENTS}

This research was supported by the research project (R2018022) managed by NIFS (National Institute of Fisheries Science).

\section{REFERENCES}

Akiduki G (2010) Egg extract promotes cell migration and growth in primary culture of early embryos in the silkworm, Bombyx mori (Lepidoptera: Bombycidae). Appl Entomol Zool 45:153-161.

Alvarez MC, Bejar J, Chen S, Hong Y (2007) Fish ES cells and applications to biotechnology. Mar Biotechnol 9: 117-127.

Bejar J, Hong Y, Alvarez MC (2002) An ES-like cell line from the marine fish Sparus aurata: Characterization and chimaera production. Transgenic Res 11:279-289.

Bryson SP, Joyce EM, Martell DJ, Lee LEJ, Holt SE, Kales SC, Fujiki K, Dixon B, Bols NC (2006) A cell line (HEW) from embryos of haddock (Melanogrammus aeglefinius) and its capacity to tolerate environmental extremes. Mar Biotechnol 8:641-653.

Chen HT (2005) Practical program evaluation: Assess and improve program planning, implementation, and effectiveness. Prev Chronic Dis 3:A25.

Chen SL, Ren GC, Sha ZX, Shi CY (2004) Establishment of a continuous embryonic cell line from Japanese flounder Paralichthys olivaceus for virus isolation. Dis Aquat Organ 60:241-246.
Chen SL, Sha ZX, Ye HQ (2003a) Establishment of a pluripotent embryonic cell line from sea perch (Lateolabrax japonicus) embryos. Aquaculture 218:141-151.

Chen SL, Ye HQ, Sha ZX, Hong Y (2003b) Derivation of a pluripotent embryonic cell line from red sea bream blastulas. J Fish Biol 63:795-805.

Fan L, Jiang J, Gao J, Song H, Liu J, Yang L, Li Z, Chen Y, Zhang Q, Wang X (2015) Identification and characterization of a PRDM14 homolog in Japanese flounder (Paralichthys olivaceus). Int J Mol Sci 16:9097-9118.

Fan Z, Liu L, Huang X, Zhao Y, Zhou L, Wang D, Wei J (2017) Establishment and growth responses of Nile tilapia embryonic stem-like cell lines under feeder-free condition. Dev Growth Differ 59:83-93.

Foresti F, Oliveira C, de Almeida-Toledo LF (1993) A method for chromosome preparations from large fish specimens using in vitro short-term treatment with colchicine. Experientia 49:810-813.

Gao J, Wang J, Jiang J, Fan L, Wang W, Liu J, Zhang Q, Wang X (2013) Identification and characterization of a nanog homolog in Japanese flounder (Paralichthys olivaceus). Gene 531:411-421.

Gao J, Wang Z, Shao K, Fan L, Yang L, Song H, Liu M, Wang Z, Wang X, Zhang Q (2014) Identification and characterization of a Sox2 homolog in the Japanese flounder Paralichthys olivaceus. Gene 544:165-176.

Gomez-Lechon MJ, Donato MT, Lahoz A, Castell JV (2008) Cell lines: A tool for in vitro drug metabolism studies. Curr Drug Metab 9:1-11.

Higaki S, Shimada M, Koyama Y, Fujioka Y, Sakai N, Takada T (2015) Development and characterization of an embryonic cell line from endangered endemic cyprinid Honmoroko Gnathopogon caerulescens (Sauvage, 1883). In Vitro Cell Dev Biol Anim 51:763-768.

Holen E, Kausland A, Skjaerven K (2010) Embryonic stem cells isolated from Atlantic cod (Gadus morhua) and the developmental expression of a stage-specific transcription factor ac-Pou2. Fish Physiol Biochem 
36:1029-1039.

Hong Y, Winkler C, Schartl M (1996) Pluripotency and differentiation of embryonic stem cell lines from the medakafish (Oryzias latipes). Mech Dev 60:33-44.

Kang MS, Oh MJ, Kim YJ, Kawai K, Jung SJ (2003) Establishment and characterization of two new cell lines derived from flounder, Paralichthys olivaceus (Temminck \& Schlegel). J Fish Dis 26:657-665.

Kasai H, Yoshimizu M (2001) Establishment of two Japanese flounder embryo cell lines. Bull Fish Sci Hokkaido Univ 52:67-70.

Kim JE, Lee YM, Lee JH, Noh JK, Kim HC, Park CJ, Park JW, Kim KK (2014) Development and validation of single nucleotide polymorphism (SNP) Markers from an expressed sequence tag (EST) database in olive flounder (Paralichthys olivaceus) Dev Reprod 18:275286.

Lachnit M, Kur E, Driever W (2008) Alterations of the cytoskeleton in all three embryonic lineages contribute to the epiboly defect of Pou5f1/Oct4 deficient MZspg zebrafish embryos. Dev Biol 315:1-17.

Lee D, Kim MS, Nam YK, Kim DS, Gong SP (2013) Establishment and characterization of permanent cell lines from Oryzias dancena embryos. Fish Aquatic Sci 16:177-185.

Liu J, You F, Wang XC, Xu YL, Zhang PJ (1999) Chromosome and karyotype evidence of artificial-induced gynogenesis in the olive flounder Paralichthys olivaceus (T. et S). Oceanol Limnol Sin 30:72-79.

Park IS, Hur JW, Choi JW (2012) Hematological responses, survival, and respiratory exchange in the olive flounder, Paralichthys olivaceus, during starvation. Asian-Australas J Anim Sci 25:1276-1284.

Peng L, Zheng Y, You F, Wu Z, Zou Y, Zhang P (2016) Establishment and characterization of a testicular Sertoli cell line from olive flounder Paralichthys olivaceus. Chin J Oceanol Limnol 34:1054-1063.

Rajpert-De Meyts E, Hanstein R, Jorgensen N, Graem N,
Vogt PH, Skakkebaek NE (2004) Developmental expression of POU5F1 (OCT-3/4) in normal and dysgenetic human gonads. Hum Reprod 19:1338-1344.

Ristow SS, de Avila J (1994) Susceptibility of four new salmonid cell lines to infectious hematopoietic necrosis virus. J Aquat Anim Health 6:260-265.

Robertson DR (1998) Do coral-reef fish faunas have a distinctive taxonomic structure? Coral Reefs 17:179-186.

Sassen WA, Lehne F, Russo G, Wargenau S, Dubel S, Koster RW (2017) Embryonic zebrafish primary cell culture for transfection and live cellular and subcellular imaging. Dev Biol 430:18-31.

Servili A, Bufalino MR, Nishikawa R, de Melo IS, Munoz-Cueto JA, Lee LEJ (2009) Establishment of long term cultures of neural stem cells from adult sea bass, Dicentrarchus labrax. Comp Biochem Physiol A Mol Integr Physiol 152:245-254.

Shimizu C, Shike H, Malicki DM, Breisch E, Westerman M, Buchanan J, Ligman HR, Phillips RB, Carlberg JM, Olst JV, Burns JC (2003) Characterization of a white bass (Morone chrysops) embryonic cell line with epithelial features. In Vitro Cell Dev Biol Anim 39:29-35.

Sun L, Bradford CS, Ghosh C, Collodi P, Barnes DW (1995) ES-like cell cultures derived from early zebrafish embryos. Mol Mar Biol Biotechnol 4:193-199.

Suzuki T, Komada H, Takai R, Arii K, Kozima TT (1995) Relation between toxicity of cryoprotectant DMSO and its concentration in several fish embryos. Fish Sci 61:193-197.

Tong SL, Miao HZ, Li H (1998) Three new continuous fish cell lines of SPH, SPS and RSBF derived from sea perch (Lateolabrax japaonicus) and red sea bream (Pagrosomus major). Aquaculture 169:143-151.

Wang XL, Wang N, Sha ZX, Chen SL (2010) Establishment, characterization of a new cell line from heart of half smooth tongue sole (Cynoglossus semilaevis). Fish physiol biochem 36:1181-1189.

Wernig M, Meissner A, Foreman R, Brambrink T, Ku M, 
Hochedlinger K, Bernstein BE, Jaenisch R (2007) In vitro reprogramming of fibroblasts into a pluripotent ES-cell-like state. Nature 448:318-324.

Wolf K, Quimby MC (1962) Established eurythermic line of fish cells in vitro. Science 135:1065-1066.

Yang J, Chai L, Liu F, Fink LM, Lin P, Silberstein LE, Amin HM, Ward DC, Ma Y (2007) Bmi-1 is a target gene for SALL4 in hematopoietic and leukemic cells. Proc Nati Acad Sci USA 104:10494-10499.

Yang J, Gao C, Chai L, Ma Y (2010) A novel SALL4/ OCT4 transcriptional feedback network for pluripotency of embryonic stem cells. PLoS ONE 5:e10766.

Yu F, Li J, Chen H, Fu J, Ray S, Huang S, Ai W (2011a) Kruppel-like factor 4 (KLF4) is required for maintenance of breast cancer stem cells and for cell migration and invasion. Oncogene 30:2161-2172.
Yu J, Chau KF, Vodyanik MA, Jiang J, Jiang Y (2011b) Efficient feeder-free episomal reprogramming with small molecules. PLoS ONE 6:e17557.

Zhang T, Rawson DM (1995) Studies on chilling sensitivity of zebrafish (Brachydanio rerio) embryos. Cryobiology 32:239-246.

Zheng WJ, Sun L (2011) Evaluation of housekeeping genes as references for quantitative real time RT-PCR analysis of gene expression in Japanese flounder $(\mathrm{Pa}$ ralichthys olivaceus). Fish Shellfish Immunol 30:638645.

Zheng Y, Peng LM, You F, Zou YX, Zhang PJ, Chen SL (2015) Establishment and characterization of a fish-cell line from the brain of Japanese flounder Paralichthys olivaceus. J Fish Biol 87:115-122. 